\title{
Diversity of rhizobia associated with Amorpha fruticosa isolated from Chinese soils and description of Mesorhizobium amorphae sp. nov.
}

\author{
E. T. Wang, ${ }^{1,3}$ P. van Berkum, ${ }^{2}$ X. H. Sui, ${ }^{3}$ D. Beyene, ${ }^{2}$ W. X. Chen ${ }^{3}$ \\ and E. Martínez-Romero'
}

Author for correspondence: E. T. Wang. Tel: +52 73 131697. Fax: +52 73175581. e-mail: ewang@cifn.unam.mx

1 Centro de Investigación sobre Fijación de Nitrógeno, UNAM, Apdo Postal 565-A, Cuernavaca, Morelos, Mexico

2 Alfalfa and Soybean Research Laboratory, Agricultural Research Service, US Department of Agriculture, Beltsville, MD 20705, USA

3 Department of Microbiology, College of Biology, China Agricultural University, Beijing 100094, People's Republic of China
Fifty-five Chinese isolates from nodules of Amorpha fruticosa were characterized and compared with the type strains of the species and genera of bacteria which form nitrogen-fixing symbioses with leguminous host plants. A polyphasic approach, which included RFLP of PCR-amplified 16S rRNA genes, multilocus enzyme electrophoresis (MLEE), DNA-DNA hybridization, 165 rRNA gene sequencing, electrophoretic plasmid profiles, cross-nodulation and a phenotypic study, was used in the comparative analysis. The isolates originated from several different sites in China and they varied in their phenotypic and genetic characteristics. The majority of the isolates had moderate to slow growth rates, produced acid on YMA and harboured a $930 \mathrm{~kb}$ symbiotic plasmid (pSym). Five different RFLP patterns were identified among the 165 rRNA genes of all the isolates. Isolates grouped by PCR-RFLP of the 165 rRNA genes were also separated into groups by variation in MLEE profiles and by DNA-DNA hybridization. A representative isolate from each of these DNA homology groups had a separate position in a phylogenetic tree as determined from sequencing analysis of the 165 rRNA genes. A new species, Mesorhizobium amorphae, is proposed for the majority of the isolates, which belonged to a moderately slow- to slow-growing, acid-producing group based upon their distinct phylogenetic position, their unique electrophoretic type, their low DNA homology with reference strains representing the species within the genus Mesorhizobium and their distinct phenotypic features. Strain ACCC 19665 was chosen as the type strain for $M$. amorphae sp. nov.

Keywords: Mesorhizobium amorphae, Amorpha fruticosa, polyphasic taxonomy, diversity, rhizobia

\section{INTRODUCTION}

Low-input sustainable agriculture depends upon the management of leguminous crops because these plants form nitrogen-fixing symbioses with five genera of bacteria belonging to the family Rhizobiaceae (Chen et al., 1988; de Lajudie et al., 1994; Dreyfus et al., 1988;

Abbreviations: $E T$, electrophoretic type; $I_{A}$ index of association; MLEE, multilocus enzyme electrophoresis.

The GenBank accession numbers for the 16S rRNA gene sequences of isolates ACCC 19665', ACCC 19667, H15003, HL56 and SH283012, and of M. tianshanense A-1BS ${ }^{\top}$ are AF041442-AF041447, respectively.
Jarvis et al., 1997; Jordan, 1984). Because of their value in agriculture, many legume species are introduced and are cultivated outside their native range. False indigo, Amorpha fruticosa, is a leguminous shrub native to the South-Eastern and Mid-Western United States (Allen \& Allen, 1981) and has been cultivated in Asia for more than half a century. Amorpha fruticosa is useful as a windbreak and as soil cover for erosion control, but also provides food for wildlife. The pods yield amorphin, which is toxic to aphids, cinch bugs and cucumber beetles, and a repellent against cattle flies. In China, the leaves are used as green manure and the seeds are a source of oil used in the manufacture of glycerol. Additional products from this plant may 
Table 1. Isolates, strains and their relevant characteristics

\begin{tabular}{|c|c|c|c|c|c|}
\hline \multirow[t]{2}{*}{ Isolate or strain* } & \multicolumn{2}{|c|}{ 16S rRNA RFLP† } & \multirow[t]{2}{*}{$\mathbf{E T} \ddagger$} & \multirow[t]{2}{*}{ Plasmid size (kb)§ } & \multirow{2}{*}{$\begin{array}{l}\text { Geographic } \\
\text { origin }\end{array}$} \\
\hline & Group & Pattern & & & \\
\hline \multicolumn{6}{|l|}{ Mesorhizobium amorphae } \\
\hline $\begin{array}{l}\text { ACCC } 19665^{\mathrm{T}}, \mathrm{ACCC} 19676, \mathrm{~B} 101, \mathrm{~B} 104, \mathrm{~B} 105, \\
\text { B106, B270, B271, B273, B274, B278, B280, B281, } \\
\text { B283, B284, B286, B287, B292 }\end{array}$ & 1 & AAAA & 1 & 930 & Beijing \\
\hline ACCC 19674, АCCC 19675, B107 & 1 & AAAA & 1 & 930,150 & Beijing \\
\hline B108 & 1 & AAAA & 1 & 930,550 & Beijing \\
\hline $\begin{array}{l}\text { ACCC 19662, ACCC 19663, B102, ACCC } \\
19664, \text { B103, B269, B272, B275, B279, B288 }\end{array}$ & 1 & AAAA & 2 & 930,550 & Beijing \\
\hline SH190012 & 1 & AAAA & 3 & 930 & Shaanxi \\
\hline $\mathrm{B} 109, \mathrm{~B} 110$ & 1 & AAAA & 4 & 930 & Beijing \\
\hline SH109 & 1 & AAAA & 4 & 930 & Shaanxi \\
\hline $\begin{array}{l}\text { ACCC 19660, ACCC 19666, ACCC } 19670, \\
\text { ACCC } 19672, \text { ACCC } 19673\end{array}$ & 1 & AAAA & 5 & 930,150 & Beijing \\
\hline B289, B291 & 1 & AAAA & 6 & 930 & Beijing \\
\hline \multicolumn{6}{|l|}{ Mesorhizobium sp. (Amorpha) } \\
\hline HL56 & 2 & BABA & 7 & 930,550 & Heilongjiang \\
\hline B276, B277, B282, B285, B290 & 2 & BABA & 8 & 930 & Beijing \\
\hline N206 & 3 & $\mathrm{ABAA}$ & 9 & 930 & Ningxia \\
\hline SH15003 & 3 & ABAA & 10 & 930 & Shaanxi \\
\hline \multicolumn{6}{|l|}{ Rhizobium sp. (Amorpha) } \\
\hline ACCC 19667, ACCC 19677 & 4 & DBDB & 11 & $930,610,490,440$ & Beijing \\
\hline \multicolumn{6}{|l|}{ Bradyrhizobium sp. (Amorpha) } \\
\hline SH28301, SH283012 & 5 & GCHE & 12 & No & Shaanxi \\
\hline \multicolumn{6}{|l|}{ Standard reference strains } \\
\hline M. huakuii CCBAU $2609^{\mathrm{T}}$ & 3 & ABAA & 16 & & \\
\hline M. tianshanense A-1BS ${ }^{\mathrm{T}}$ & 2 & BABA & 17 & & \\
\hline M. ciceri UPM-Ca $7^{\mathrm{T}}$ & 13 & CABA & 15 & & \\
\hline M. loti NZP $2213^{\mathrm{T}}$ & 12 & ABCA & 13 & & \\
\hline M. mediterraneum UPM-Ca $36^{\mathrm{T}}$ & 12 & $\mathrm{ABCA}$ & 14 & & \\
\hline M. plurifarium ORS 1037 & 17 & AAKA & 18 & & \\
\hline R. etli CFN $42^{\mathrm{T}}$ & 9 & DBEC & & $\begin{array}{l}630,510,390,270 \\
170,150\end{array}$ & \\
\hline R. tropici A CFN 299 & 8 & EBFD & & $>1000,410,225,185$ & \\
\hline R. tropici B CIAT $899^{\mathrm{T}}$ & 7 & FBDB & & & \\
\hline R. leguminosarum USDA $2370^{\mathrm{T}}$ & 4 & DBDB & 19 & & \\
\hline R. galegae HAMBI $540^{\mathrm{T}}$ & 6 & GBDA & & & \\
\hline A. caulinodans ORS $571^{\mathrm{T}}$ & 14 & HBGC & & & \\
\hline S. meliloti USDA $1002^{\mathrm{T}}$ & 18 & FBIF & & & \\
\hline S. fredii USDA $205^{\mathrm{T}}$ & 19 & KBJF & & & \\
\hline S. saheli ORS $609^{\mathrm{T}}$ & 11 & LBIF & & & \\
\hline S. terangae ORS $1009^{\mathrm{T}}$ & 10 & LBIA & & & \\
\hline B. japonicum USDA $6^{\mathrm{T}}$ & 15 & MDLH & & & \\
\hline B. japonicum USDA 110 & 15 & MDLH & & & \\
\hline B. elkanii USDA $76^{\mathrm{T}}$ & 16 & NEMH & 20 & & \\
\hline \multicolumn{6}{|l|}{ Plasmid or cosmid } \\
\hline pMR133 & \multirow{2}{*}{\multicolumn{5}{|c|}{$\begin{array}{l}\text { A } 2.0 \mathrm{~kb} \text { insert of the nodDAB of } R \text {. tropici CFN } 299 \text { cloned into pUC18 } \\
\text { (unpublished) } \\
\text { pSup } 205 \text { derivative with region nifKDH of } R \text {. etli CFN } 42^{\mathrm{T}} \text { (Morett et al., } \\
\text { 1988) }\end{array}$}} \\
\hline pEM15 & & & & & \\
\hline
\end{tabular}

For footnotes see facing page. 
have pharmaceutical properties (Konoshima et al., 1993; Mitscher et al., 1981).

The import of legumes from their native habitats and their cultivation as an introduced crop may significantly impact the microbiology within soils. The rhizobia specific for the introduced crop may be transmitted along with the host and subsequently may establish a symbiosis and populate the new soil environment. The introduction of these specific rhizobia may occur either by management through inoculation, or by seed-borne bacteria as described for common bean seeds (Pérez-Ramirez et al., 1998). Occasionally, remnants of a rhizobial population which have lost symbiotic determinants may become recipients of genetic information from closely related inoculated strains, acquiring the ability for symbiosis with an introduced legume host as was reported for Lotus corniculatus in New Zealand (Sullivan et al., 1995, 1996). The possibility also exists that exotic legumes are nodulated by rhizobia which are members of the local soil population. For instance, common beans normally form symbioses with Rhizobium etli in their native habitat (Piñero et al., 1988; Segovia et al., 1993), but in Europe they may be nodulated by the two newly proposed species Rhizobium giardinii and Rhizobium gallicum (Amarger et al., 1997). The ability of an introduced legume species to form symbioses with local rhizobia can vary according to host promiscuity. In the case of common bean, promiscuity is evident from its ability to be nodulated by Rhizobium leguminosarum (Eardly et al., 1995; Young, 1985), Rhizobium tropici (Martínez-Romero et al., 1991) and Rhizobium mongolense (van Berkum et al., 1998a), in addition to $R$. gallicum and $R$. giardinii (Amarger et al., 1997).

The rhizobia associated with Amorpha fruticosa originating from soils of the legume's native habitat have not been studied and no molecular evolutionary characterization of these bacteria has been reported. In China, Amorpha fruticosa is nodulated without inoculation, but limited information is available about the rhizobia which form these symbioses. Six isolates originating from Amorpha fruticosa growing in China were clustered into two phenotypic groups in a numerical analysis which included isolates from other host legumes (unpublished data). Several isolates from Japan were related to Mesorhizobium loti based upon partial sequence analysis of their 16S rRNA genes (Oyaizu et al., 1993). Because so little information is available about the rhizobia of Amorpha fruticosa, our objective was to characterize isolates from nodules of plants growing in Chinese soils using a polyphasic approach.

\section{METHODS}

Isolates and strains. The isolates and reference strains used in this study are shown in Table 1. Fifty-five isolates were obtained from three different geographic regions in Northern China. Forty-eight isolates originated from the Western suburbs of Beijing. One isolate was from Heilongjiang Province, which is in North-Eastern China approximately $1000 \mathrm{~km}$ from Beijing, and six were from Ningxia and Shaanxi Provinces, which are in North-Western China, approximately $1000 \mathrm{~km}$ from Beijing and $2000 \mathrm{~km}$ from Heilongjiang Province. The ACCC isolates (from the Agricultural Center Culture Collection, Chinese Academy of Agriculture, Beijing, China) and isolates B101-B292 were obtained in 1985 and 1995, respectively. The remaining isolates were collected in 1993. The plants from which isolations were made were grown in soils poor in organic matter $(<0.1 \%)$ without the addition of fertilizer. Isolations were made according to the procedure described by Vincent (1970) using yeast mannitol agar (YMA). Cultures used for further study were purified from single colonies on YMA or MAG (van Berkum, 1990) agar plates after $7 \mathrm{~d}$ incubation at $28^{\circ} \mathrm{C}$.

Symbiotic performance. Seeds of Amorpha fruticosa were scarified with fine sandpaper and were surface-sterilized with $1 \%(\mathrm{v} / \mathrm{v}) \mathrm{NaOCl}$ solution for $3 \mathrm{~min}$. Germination was on moist paper towels or on $0.75 \%$ water-agar plates. Germinated seedlings were planted in Leonard jars (Leonard, 1943) containing sterile vermiculite moistened with nitrogen-free nutrition solution as described previously (van Berkum, 1990). Five millilitres of a 1- or 2-d-old MAG culture for the fast- or slow-growing isolates, respectively, was used to inoculate six seedlings in each jar. Nodulation was examined after 4 weeks growth in a growth room with day and night cycles of 16 and $8 \mathrm{~h}$, and temperatures of 25 and $20{ }^{\circ} \mathrm{C}$, respectively. The selected hosts recommended by Graham et al. (1991) and also Astragalus sinicus, Cicer arietinum and Glycyrrhiza uralensis were examined for nodulation by isolates ACCC $19665^{\mathrm{T}}$, ACCC 19667 and SH283012. Nodulation of Amorpha fruticosa by the type strains of described species was also investigated. The cross-

No, No plasmid observed.

* ACCC, Agricultural Center Culture Collection, Chinese Academy of Agriculture, Beijing, China; CCBAU, Culture Collection of Beijing Agriculture University, Beijing, China; CFN, Centro de Investigación sobre Fijación de Nitrógeno, UNAM, Cuernavaca, México; CIAT, Centro Internacional de Agricultura Tropical, Cali, Columbia; HAMBI, Culture Collection of the Department of Microbiology, University of Helsinki, Helsinki, Finland; NZP, Division of Scientific and Industrial Research, Palmerston North, New Zealand; ORS, ORSTOM Collection, Institut Français de Recherche Scientifique pour le Développement en Coopération, Dakar, Senegal; USDA, Beltsville Rhizobium Culture Collection, Beltsville Agricultural Research Center, Beltsville, MD, USA.

$\dagger$ Four letters were arbitrarily assigned to represent specific fingerprint patterns obtained from PCR-RFLP analysis of 16S rRNA genes digested with restriction endonucleases $M s p \mathrm{I}$, HinfI, $H h a \mathrm{I}$ and Sau $3 \mathrm{AI}$, respectively. Different combinations of letters were then used to define RFLP groups.

$\ddagger$ Electrophoretic type representing different combinations of nine enzyme patterns distinguishable with starch gel electrophoresis. $\S$ The approximate plasmid sizes were calculated from their mobilities in $0.7 \%$ agarose gel with plasmids of $R$. etli CFN $42^{\mathrm{T}}$ as molecular size standard marker and $R$. tropici CFN 299 as reference. The standard deviation was $12 \mathrm{~kb}$. 
nodulation tests were done in sterilized plastic cups filled with vermiculite and the plants were grown in sunlight as described previously (Wang et al., 1998).

PCR-RFLP analysis and determination of nucleotide sequences of the 16S rRNA genes. The PCR procedure described by van Berkum et al. (1996) was used for amplification of the 16S rRNA gene fragments (approximately $1500 \mathrm{bp}$ ) using primers fD1 (5' AGAGTTTGATCCTGGCTCAG 3') and rD1 (5' AAGGAGGTGATCCAGCC $3^{\prime}$ ) (Weisburg et al., 1991), which corresponded to positions 8-27 and 1524-1540, respectively, of the Escherichia coli $16 \mathrm{~S}$ rRNA gene. The products in $10 \mu \mathrm{l}$ subsamples of the reaction mixtures were digested with $5 \mathrm{U}$ each of HhaI, HinfI, MspI or Sau3AI and the restriction fragments were separated by electrophoresis in $2 \%(\mathrm{w} / \mathrm{v})$ agarose gels (Laguerre et al., 1994). Similarities among the $16 \mathrm{~S}$ rRNA gene sequences were estimated from the proportion of shared restriction fragments (Nei \& Li, 1979) and a dendrogram was constructed from the resulting distance matrix using the unweighted pair group method with averages (UPGMA) (Sneath \& Sokal, 1973). Template DNAs were prepared from $50 \mathrm{ml}$ MAG-grown cells of isolates ACCC 19665' ${ }^{\mathrm{T}}$, HL56, SH15003, ACCC 19667 and SH283012, and the type strain of Mesorhizobium tianshanense, $\mathrm{A}-1 \mathrm{BS}^{\mathrm{T}}$. These were purified by $\mathrm{CsCl}$ ultracentrifugation (Navarro et al., 1993) and were used to generate the PCR products of the 16S rRNA genes for sequencing analysis. Full-length sequences of the 16S rRNA genes were determined with purified PCR products and an Applied Biosystems International 373 DNA Sequencer using a Dye Deoxy Terminator Cycle Sequencing Kit as described previously (van Berkum et al., 1996).

Analysis of the sequence data. The sequences were aligned using the PILEUP program in the Wisconsin package of the Genetics Computer Group (Madison, WI, USA). Aligned sequences were analysed using the Molecular Evolutionary Genetics Analysis (MEGA) package version 1.01 (Kumar et al., 1993) to produce a Jukes-Cantor distance matrix (Jukes \& Cantor, 1969) and to construct an optimal unrooted tree using the neighbour-joining method (Saitou \& Nei, 1987). This package was also used to generate bootstrap confidence values from 500 replications of each sequence and to derive the nucleotide sequence similarities of the 16S rRNA genes.

Multilocus enzyme electrophoresis (MLEE). Culture extracts for MLEE analysis were prepared from $40 \mathrm{ml}$ PY (Noel et al., 1984) broth cultures grown overnight at $28^{\circ} \mathrm{C}$ and were stored according to the procedure of Caballero-Mellado \& Martínez-Romero (1994). Starch gel electrophoresis and selective staining for the nine metabolic enzymes malic enzyme, isocitrate dehydrogenase, glucose-6-phosphate dehydrogenase, NADP-independent glutamate dehydrogenase, indophenol oxidase, phosphoglucomutase, hexokinase, esterase and phosphoglucose isomerase were done according to the procedures described by Selander et al. (1986). Distinctive mobility variants (electromorphs) of each enzyme, numbered in order of decreasing anodal mobility, were equated with alleles at the corresponding structural gene locus. Allele profiles or electrophoretic types (ETs) were equated with multilocus genotypes. The genetic distance between pairs of ETs was estimated as the proportion of loci at which dissimilar alleles (mismatches) occurred. Clustering of ETs from a matrix of pairwise genetic distances was by the method described by Nei \& Li (1979). Genetic diversity $(h)$ at an enzyme locus was calculated as $h=\left[1-\Sigma x_{i}^{2}\right][n /(n-1)]$, where $x_{i}$ is the frequency of the $i$ th allele at the locus and $n$ is the number of ETs in the population. The extent of linkage disequilibrium (nonrandom combinations of alleles) among ETs was estimated by comparing observed and expected moments of allelic mismatch frequency distributions. An 'index of association' or $I_{\mathrm{A}}$, originally described by Brown et al. (1980) was used to demonstrate a non-random association of alleles. Equations for the calculation of $I_{\mathrm{A}}$ and its associated error variance are described by Maynard Smith et al. (1993). A Monte Carlo procedure with 10000 iterations as recommended by Souza et al. (1992) was used to estimate the extent of linkage disequilibrium.

Determination of DNA base composition and DNA-DNA hybridization. Cultures were grown in $5.0 \mathrm{ml}$ PY broth at $28^{\circ} \mathrm{C}$ until late-exponential phase and were centrifuged at $12000 \mathrm{~g}$ for DNA preparation using a DNA/RNA isolation kit from USB as described by Chirgwin et al. (1979). These samples were used to estimate DNA $\mathrm{G}+\mathrm{C}$ content $\left(T_{\mathrm{m}}\right)$ by the method of De Ley (1970) and to estimate DNA homologies by using the filter method as described by van Berkum et al. (1996).

Plasmid content and identification of the symbiotic plasmid. The plasmid contents of each of the isolates and each of the type strains for each species within the genus Mesorhizobium were visualized using a modified Eckhardt procedure (Eckhardt, 1978; Hynes \& McGregor, 1990). Plasmid mobilities determined in $0.7 \%$ agarose gels were used for estimating the approximate molecular sizes of plasmids with the computer program Seqaid II version 3.5 (Rhoads \& Roufa, 1989). The plasmids of $R$. etli CFN $42^{\mathrm{T}}$ (Romero et al., 1991) and of $R$. tropici CFN 299 (Geniaux et al., 1995; Martínez et al., 1987) were used as reference molecular size markers. Symbiotic plasmids were identified by Southern hybridization analysis using as probes a $2.0 \mathrm{~kb}$ EcoRI-Pst I fragment containing nodDAB of $R$. tropici CFN 299 cloned in pUC18 (unpublished) and a $5 \cdot 1 \mathrm{~kb} B a m H I$ restriction fragment containing nifHDK of $R$. etli CFN $42^{\mathrm{T}}$ (Morett et al., 1988) as described previously (Wang et al., 1998). The type strain of $R$. etli, CFN 42, and the type A strain of $R$. tropici, CFN 299, were used as positive controls.

Determination of reiteration of nifH. Reiteration of nifH was determined by Southern hybridization analysis as described above for plasmid hybridization. A 600 bp SalI fragment carrying nifH of $R$. etli (Morett et al., 1988) as probe and total genomic EcoRI or BamHI digests were used. The type A strain of $R$. tropici, CFN 299, was used as a reference.

Phenotypic characterization. The phenotypic characters of 55 isolates from Amorpha fruticosa and the type strains of the described species were examined by recording growth after incubation times of 3 or $7 \mathrm{~d}$ for fast- and moderately slow-growing cultures, respectively. Reference strains used in phenotypic characterization were $R$. leguminosarum USDA $2370^{\mathrm{T}}$, Sinorhizobium fredii USDA $205^{\mathrm{T}}, M$. lot $i$ NZP $2213^{\mathrm{T}}, M$. tianshanense A-1BS ${ }^{\mathrm{T}}$, Bradyrhizobium japonicum USDA $6^{\mathrm{T}}$ and USDA 110 , and Bradyrhizobium elkanii USDA $76^{\mathrm{T}}$. Resistance to the presence of agar diffusion discs containing $10 \mu \mathrm{g}$ ampicillin, $10 \mathrm{U}$ bacitracin, $75 \mu \mathrm{g}$ cefoperazone, $30 \mu \mathrm{g}$ cefuroxime, $5 \mu \mathrm{g}$ ciprofloxacin, $30 \mu \mathrm{g}$ novobiocin, $10 \mathrm{U}$ penicillin $\mathrm{G}, 100 \mathrm{U}$ polymyxin $\mathrm{B}, 10 \mu \mathrm{g}$ streptomycin and $30 \mu \mathrm{g}$ tetracycline (Difco) was determined by growth on MAG as reported previously (van Berkum et al., 1998a). The method and agar basal medium described by Ladha \& So (1994) were used to investigate utilization of sole carbon substrates for growth. Filter-sterilized acetate, 
L-arabinose, alanine, citrate, D-fructose, fumarate, D-glucose, L-leucine, L-lysine, meso-inositol, DL-malate, malonate, maltose, L-ornithine, D-raffinose, saccharic acid, sorbose, sucrose and xylose were added to the sterile basal medium at a final concentration of $0 \cdot 2 \%$. Basal medium supplemented with $0.2 \%$ mannitol or without addition of carbon substrate was used as the positive and negative control, respectively. The same basal medium was used to test the use of amino acids as the sole nitrogen sources for growth. Filter-sterilized arginine, glycine, lysine, methionine, phenylalanine, threonine, tryptophan and tyrosine were added to the sterilized basal medium at a final concentration of $10 \mathrm{mM}$. Basal medium containing $0.01 \%\left(\mathrm{NH}_{4}\right)_{2} \mathrm{SO}_{4}$ or without the addition of a nitrogen substrate was used as the positive and negative control, respectively. The appearance of single colonies was scored as positive.

Tolerance to $\mathrm{NaCl}$ at concentrations of $1 \cdot 0,1 \cdot 5,2 \cdot 0,2 \cdot 5$ and $3.0 \%(\mathrm{w} / \mathrm{v})$ was determined by growth on supplemented YMA. Ability to grow at 37 and $40^{\circ} \mathrm{C}$, and the ability to grow at $\mathrm{pH} 5 \cdot 0,9.0$ or 9.5 were also determined on YMA. Acid/alkali production in litmus milk was recorded after $28 \mathrm{~d}$ incubation in Difco litmus milk medium. Ability to grow in LB (nutrition) broth (Yanagi \& Yamasato, 1993) was determined with $5 \mathrm{ml}$ medium. Production of acid or alkali was examined on YMA supplemented with $0.0025 \%$ bromothymol blue as $\mathrm{pH}$ indicator (van Berkum, 1990). Growth rates of isolates ACCC 19660, ACCC 19663, ACCC 19665 ${ }^{\mathrm{T}}$, B101, B289, SH109, SH19012, HL56, B276, N206, SH15003, ACCC 19667, ACCC 19677, SH28301 and SH283012, which represented each of the five 16S rRNA gene patterns, were determined in YM broth by following the increase in culture optical density at $600 \mathrm{~nm}$ (Yelton et al., 1983) with a Beckman DU 650 spectrophotometer every $4 \mathrm{~h}$ for the faster growing cultures and every $12 \mathrm{~h}$ for more slowly growing cultures. Cell shape and size were determined by Gram-staining and microscopy.

\section{RESULTS}

\section{Isolation and nodulation}

Most of the 55 isolates grew moderately slowly to slowly, produced acid and were effective for symbiotic nitrogen fixation on the original trap host. Amorpha fruticosa formed determinate nodules with diameters of $1-4 \mathrm{~mm}$ on plants which were 4 weeks old. The isolates ACCC 19667 and ACCC 19677 differed from the other 53 by exhibiting faster growth since they formed colonies larger than $2 \mathrm{~mm}$ in diameter after $3 \mathrm{~d}$ incubation, and by forming nodules on Amorpha fruticosa which were ineffective for nitrogen fixation. Isolates HL56, SH283012 and SH28301 also differed in symbiotic response since they were only moderately effective for nitrogen fixation with Amorpha fruticosa.

Nodulation of Amorpha fruticosa was also observed in response to inoculation with $R$. tropici strain CFN 299. However, $R$. leguminosarum USDA $2370^{\mathrm{T}}, R$. tropici CIAT $899^{\mathrm{T}}, R$. etli CFN $42^{\mathrm{T}}$, Rhizobium galegae HAMBI $540^{\mathrm{T}}$, Sinorhizobium meliloti USDA $1002^{\mathrm{T}}, S$. fredii USDA $205^{\mathrm{T}}$, Sinorhizobium saheli ORS $609^{\mathrm{T}}$, Sinorhizobium terangae ORS $1009^{\mathrm{T}}, M$. loti NZP $2213^{\mathrm{T}}$, Mesorhizobium huakuii CCBAU $2609^{\mathrm{T}}$, Mesorhizobium ciceri UPM-Ca $7^{\mathrm{T}}$, Mesorhizobium medit- erraneum UPM-Ca36 ${ }^{\mathrm{T}}, M$. tianshanense A-1BS ${ }^{\mathrm{T}}$, Mesorhizobium plurifarium ORS $1037, B$. japonicum USDA $6^{\mathbf{T}}, B$. elkanii USDA $76^{\mathrm{T}}$ and Azorhizobium caulinodans ORS $571^{\mathrm{T}}$ did not nodulate Amorpha fruticosa. Isolate ACCC $19665^{\mathrm{T}}$, representing the main group (group 1) of the isolates, failed to nodulate Astragalus sinicus, Cicer arietinum, Galega officinalis, Glycine max, Glycyrrhiza uralensis, Leucaena leucocephala, Lotus corniculatus, Macroptilium atropurpureum, Medicago sativa, Phaseolus vulgaris, Pisum sativum, Trifolium albus and Vigna unguiculata. Also, strain ACCC 19667 did not nodulate Phaseolus vulgaris and Pisium sativum, whilst SH283012 did not nodulate Glycine max.

\section{RFLP of 165 rRNA genes}

Five distinct RFLP patterns with the PCR-amplified $16 \mathrm{~S}$ rRNA genes were identified among the isolates from Amorpha fruticosa and were used to define groups 1-5 (Table 1). The majority of the isolates (43) had identical fingerprint patterns (pattern AAAA). These isolates originated from Beijing and Shaanxi Province. The second-most prevalant PCR-RFLP pattern (pattern BABA) was observed in six isolates which originated from Beijing and Heilongjiang Province. Each of the other three PCR-RFLP patterns (ABAA, DBDB and GCHE) were observed in analyses with the remaining six isolates. The five PCR-RFLP patterns observed among the isolates from Amorpha fruticosa were compared to those obtained with strains representing the bacterial species and genera forming symbioses with leguminous host plants. The first and the last patterns (AAAA and GCHE) were distinct from those observed with the reference strains (Table 1). From clustering analysis of the PCR-RFLP data we concluded that the $16 \mathrm{~S}$ rRNA genes of the isolates within these two groups were characteristic of the genera Mesorhizobium and Bradyrhizobium (Fig. 1). The remaining three patterns were characteristic of the type strains for $M$. tianshanense, $M$. huakuii or $R$. leguminosarum. The described species formed clusters according to their estimated phylogeny based on the 16S rRNA gene nucleotide sequences (Amarger et al., 1997; de Lajudie et al., 1994; van Berkum et al., 1998a, Wang et al., 1998).

\section{MLEE analysis}

The 55 isolates were analysed for variation in electrophoretic mobility of nine enzyme loci. A total of 12 distinctive multilocus ETs were identified (Table 1). The largest number of isolates in any single ET was twenty-two, which is represented by strain ACCC $19665^{T}$ (Tables 1 and 2). Across all 55 isolates, the enzymes were polymorphic with two to eight alleles per locus (Table 2). However, across the majority of the isolates (43 isolates from ET 1-ET 6), only three enzymes were polymorphic (Table 2 ). Across all the isolates, the $h$ values per enzyme locus ranged from 


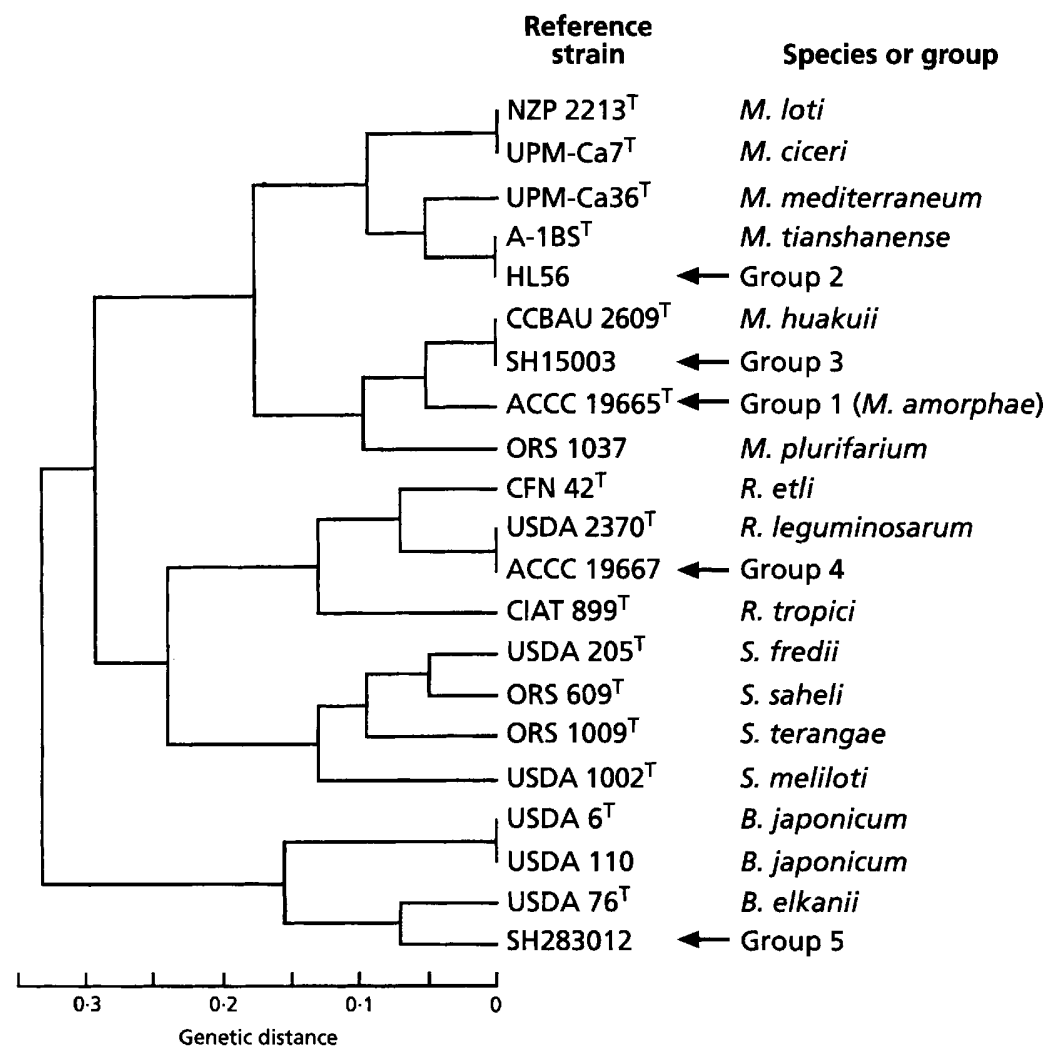

Fig. 1. Dendrogram showing the preliminary phylogenetic positions of isolates from Amorpha fruticosa based on the RFLP patterns of PCR-amplified 165 genes. Clustering analysis was performed using the method of Nei \& $\mathrm{Li}$ (1979) from the genetic distance estimated from the fragments shared by each strain pair. The five groups, represented by isolates marked with arrows, consist of a total of 55 isolates from Amorpha fruticosa growing in Chinese soils, divided according to RFLP patterns. Isolates within each group shared the same RFLP patterns when digested with Mspl, Hinfl, Hhal or Sau3Al.

Table 2. Genetic diversity ( $h$ values) at nine enzyme loci among isolates from Amorpha fruticosa

\begin{tabular}{|c|c|c|c|c|c|c|}
\hline \multirow[t]{2}{*}{ Enzyme locus* } & \multicolumn{2}{|c|}{ Group $1(6 \mathrm{ETs}) \dagger$} & \multicolumn{2}{|c|}{ Mesorhizobium (10 ETs) } & \multicolumn{2}{|c|}{ All isolates (12 ETs) } \\
\hline & No. of alleles & $h$ value & No. of alleles & $h$ value & No. of alleles & $h$ value \\
\hline EST & 3 & 0.733 & 6 & $0 \cdot 889$ & 8 & 0.909 \\
\hline IPO & 1 & 0 & 2 & 0.356 & 4 & 0.394 \\
\hline ME & 1 & 0 & 2 & 0.467 & 2 & $0 \cdot 530$ \\
\hline G6P & 1 & 0 & 2 & $0 \cdot 200$ & 4 & 0.455 \\
\hline IDH & 2 & 0.600 & 3 & 0.733 & 5 & 0.927 \\
\hline GD2 & 1 & 0 & 3 & 0.600 & 5 & $0 \cdot 728$ \\
\hline HEX & 1 & 0 & 3 & 0.511 & 5 & 0.669 \\
\hline PGM & 1 & 0 & 3 & $0 \cdot 356$ & 4 & $0 \cdot 394$ \\
\hline PGI & 3 & 0.600 & 4 & 0.800 & 5 & 0.833 \\
\hline Mean & 1.6 & $0 \cdot 214$ & $3 \cdot 1$ & 0.546 & $4 \cdot 7$ & 0.649 \\
\hline$I_{\mathrm{A}}$ value & \multicolumn{2}{|c|}{$-0.06 \pm 0.28$} & \multicolumn{2}{|c|}{$2 \cdot 44 \pm 0 \cdot 25$} & \multicolumn{2}{|c|}{$3 \cdot 04 \pm 0 \cdot 20$} \\
\hline
\end{tabular}

*EST, esterase; IPO, indophenol oxidase; ME, NADP-malate dehydrogenase; G6P, glucose-6-phosphate dehydrogenase; IDH, isocitrate dehydrogenase; GD2, NADP-dependent glutamate dehydrogenase; HEX, hexokinase; PGM, phosphoglucomutase; PGI, phosphoglucose isomerase.

$\dagger$ Groups defined on the basis of PCR-RFLP analysis of 16S rRNA genes (see Table 1).

0.39 to 0.93 . When the most divergent isolates were omitted from the analysis (isolates from ET 11 and ET 12 ), the $h$ values ranged from $0 \cdot 20$ to $0 \cdot 89$, whilst across isolates belonging to ET 1-ET 6, the $h$ values ranged from 0 to 0.73 (Table 2 ). The overall mean diversity per locus $(h)$ of all isolates was $0 \cdot 65$. A dendrogram illustrating the relative genetic distance among the twelve ETs is shown in Fig. 2. The isolates within each of the clusters derived from the MLEE data had the same 16S rRNA gene PCR-RFLP fingerprint patterns. Exceptions were isolates N206 and SH15003, which were separated in clustering analysis of the MLEE data even though they had generated identical PCRRFLP patterns in the analysis of the 16S rRNA genes. 


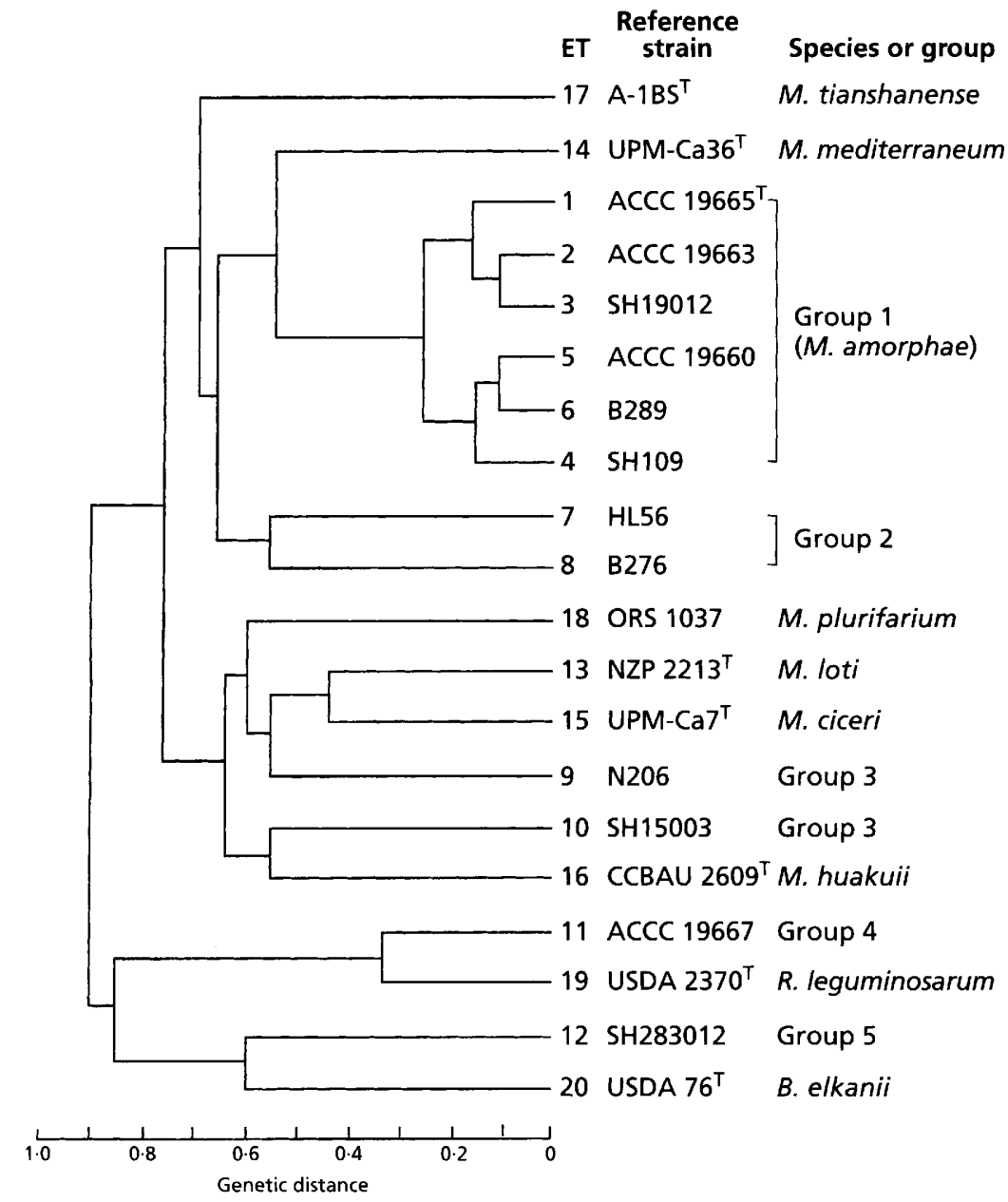

Fig. 2. Genetic relationships derived from MLEE studies on isolates obtained from Amorpha fruticosa and type strains representing species of Mesorhizobium, $R$. leguminosarum and $B$. elkanii. A total of 55 isolates from Amorpha fruticosa were represented by the 12 ETs observed. Groups were defined by RFLP patterns of PCRamplified 165 rRNA genes.
Forty-nine of the isolates were in two distinct groups represented by eight ETs. The remaining six isolates (four ETs) were either associated with the type strains for Mesorhizobium (ET 9 and 10) or clustered with $R$. leguminosarum (ET 11) or with B. elkanii (ET 12).

The observed variance of the ET mismatch distribution for the first ten ETs, which represented all Mesorhizobium isolates, was significantly larger than expected $\left(I_{\mathrm{A}}=2 \cdot 44 \pm 0 \cdot 25\right)$, implying a clonal population structure among the chromosomal lineages (Table 2). Further subdivision of the isolates into the first six ETs (group 1) resulted in an $I_{\mathrm{A}}$ value $(-0 \cdot 06 \pm 0 \cdot 28)$ that did not significantly differ from zero.

\section{Determination of DNA G + C content and DNA hybridization}

In Table 3 are listed the isolates which we chose to represent our collection for the purpose of determining DNA homology and DNA G + C contents. The DNA $\mathrm{G}+\mathrm{C}$ values among these isolates varied from 61 to $64 \mathrm{~mol} \%$, which is within the range expected for rhizobia. DNA homologies between isolates within the same PCR-RFLP group ranged from 64 to $100 \%$ (Table 3). Across isolates with different RFLP patterns, the DNA homologies ranged from 10 to
$50 \%$. With the exception of ACCC 19667, the DNA homologies between the isolates and the reference strains for the species ranged from 7 to $37 \%$ (Table 3 ). In the case of isolate ACCC 19667, the DNA homology with the type strain for $R$. leguminosarum (USDA 2370 ) was $70 \%$.

\section{Phylogeny of the isolates}

Phylogeny was reconstructed from 16S rRNA gene sequences of single isolates each representing the five different patterns identified in the PCR-RFLP analysis. The majority of the isolates, represented by ACCC $19665^{\mathrm{T}}$, SH15003 and HL56, were grouped with species in the genus Mesorhizobium (Fig. 3). The isolates ACCC $19665^{\mathrm{T}}$ and SH15003 clustered with type strains for $M$. huakuii, $M$. mediterraneum and $M$. tianshanense, whilst isolate HL56 was more closely related to $M$. loti and $M$. ciceri.

We also determined the 16S rRNA gene sequence of the type strain for $M$. tianshanense because the fulllength sequence reported by Tan et al. (1997) and the partial sequence reported by Chen et al. (1995) over the same $260 \mathrm{bp}$ region differed by six nucleotides. The 
Table 3. DNA-DNA homologies among the reference strains for isolates from Amorpha fruticosa and type strains for described species

The membranes were hybridized overnight at $65^{\circ} \mathrm{C}$ and washed twice in $2 \times \mathrm{SSC}$ at room temperature for $10 \mathrm{~min}$ and in $1 \times \mathrm{SSC}$ at $65^{\circ} \mathrm{C}$ for $15 \mathrm{~min}$. Values are means \pm standard error.

\begin{tabular}{|c|c|c|c|c|c|}
\hline \multirow[t]{2}{*}{ Isolate or strain* } & \multicolumn{5}{|c|}{ DNA homology with reference strain (\%) } \\
\hline & $\operatorname{ACCC} 19665^{T}$ & HL56 & SH15003 & ACCC 19667 & SH283012 \\
\hline \multicolumn{6}{|l|}{ Group 1 (M. amorphae) } \\
\hline ACCC $19665^{\mathrm{T}}$ & 100 & $44 \pm 9$ & $35 \pm 0$ & & \\
\hline B101 & $80 \pm 16$ & & & & \\
\hline ACCC 19663 & $85 \pm 3$ & & & & \\
\hline SH19012 & $75 \pm 0$ & & & & \\
\hline SH109 & $76 \pm 8$ & & & & \\
\hline ACCC 19660 & $86 \pm 0$ & & & & \\
\hline B289 & $95 \pm 7$ & & & & \\
\hline \multicolumn{6}{|l|}{ Group 2} \\
\hline B276 & & $67 \pm 2$ & & & \\
\hline HL56 & $45 \pm 3$ & 100 & $50 \pm 2$ & & \\
\hline \multicolumn{6}{|l|}{ Group 3} \\
\hline N206 & $40 \pm 1$ & $37 \pm 8$ & $64 \pm 0$ & & \\
\hline SH15003 & $42 \pm 5$ & $40 \pm 1$ & 100 & & \\
\hline \multicolumn{6}{|l|}{ Group 4 (Rhizobium sp.) } \\
\hline ACCC 19667 & $10 \pm 2$ & & & 100 & \\
\hline ACCC 19677 & & & & 100 & \\
\hline \multicolumn{6}{|l|}{ Group 5 (Bradyrhizobium sp.) } \\
\hline SH 283012 & $19 \pm 5$ & $18 \pm 1$ & $10 \pm 1$ & & 100 \\
\hline SH28301 & & & $8 \pm 0$ & & 95 \\
\hline M. loti NZP $2213^{\mathrm{T}}$ & $35 \pm 0$ & $37 \pm 0$ & $32 \pm 0$ & & $13 \pm 3$ \\
\hline M. mediterraneum UPM-Ca36 & $29 \pm 1$ & $31 \pm 7$ & $22 \pm 3$ & & \\
\hline M. ciceri $\mathrm{UPM}-\mathrm{Ca} 7^{\mathrm{T}}$ & $30 \pm 1$ & $25 \pm 2$ & $17 \pm 1$ & & \\
\hline M. huakuii CCBAU 2609 & $23 \pm 4$ & $33 \pm 5$ & $26 \pm 1$ & & \\
\hline M. plurifarium ORS 1037 & $33 \pm 0$ & $25 \pm 5$ & $21 \pm 3$ & & \\
\hline M. tianshanense $\mathrm{A}-1 \mathrm{BS}^{\mathrm{T}}$ & $24 \pm 3$ & $20 \pm 4$ & $22 \pm 1$ & & \\
\hline S. meliloti USDA $1002^{\mathrm{T}}$ & $7 \pm 1$ & & & & \\
\hline S. fredii USDA $205^{\mathrm{T}}$ & $7 \pm 1$ & & & & $11 \pm 1$ \\
\hline S. saheli ORS $609^{\mathrm{T}}$ & $10 \pm 1$ & & & & \\
\hline S. terangae ORS $1009^{\mathrm{T}}$ & $11 \pm 0$ & & & & \\
\hline R. leguminosarum USDA $2370^{\mathrm{T}}$ & $7 \pm 0$ & & & $70 \pm 2$ & 7 \\
\hline R. tropici B CIAT $899^{\mathrm{T}}$ & $17 \pm 1$ & $37 \pm 5$ & & & $17 \pm 0$ \\
\hline R. tropici A CFN 299 & $14 \pm 0$ & & & $26 \pm 0$ & \\
\hline R. etli $\mathrm{CFN} 42^{\mathrm{T}}$ & $11 \pm 1$ & & & $34 \pm 5$ & \\
\hline R. galegae HAMBI $540^{\mathrm{T}}$ & $17 \pm 0$ & & & & \\
\hline B. elkanii USDA $76^{\mathrm{T}}$ & 7 & & & & $32 \pm 0$ \\
\hline B. japonicum USDA $6^{\mathrm{T}}$ & $7 \pm 2$ & & & & $19 \pm 0$ \\
\hline A. caulinodans ORS $571^{\mathrm{T}}$ & $8 \pm 1$ & & & & \\
\hline
\end{tabular}

* Groups defined on the basis of PCR-RFLP analysis of 16S rRNA genes (see Table 1).

sequence we report for $M$. tianshanense in the same $250 \mathrm{bp}$ region was $1 \mathrm{bp}$ different to that reported by Chen et al. (1995). We used PCR products directly as templates for sequencing, whilst Tan et al. (1997) used a cloned PCR fragment. This difference in methodology may explain the disparity of the results since Mesorhizobium harbours two 16S rRNA genes (van Berkum et al., 1998b) and they may show sequence heterogeneity (Cilia et al., 1996; Wang et al., 1997). Since the 16S rRNA gene nucleotide sequence determined by Tan et al. (1997) and by us differ, reconstructions of the phylogeny also differ. In our case, the estimated similarities of the 16S rRNA genes were 99.6 and $99.1 \%$ between $M$. tianshanense and $M$. mediterraneum, and between $M$. tianshanense and $M$. huakuii, respectively. 


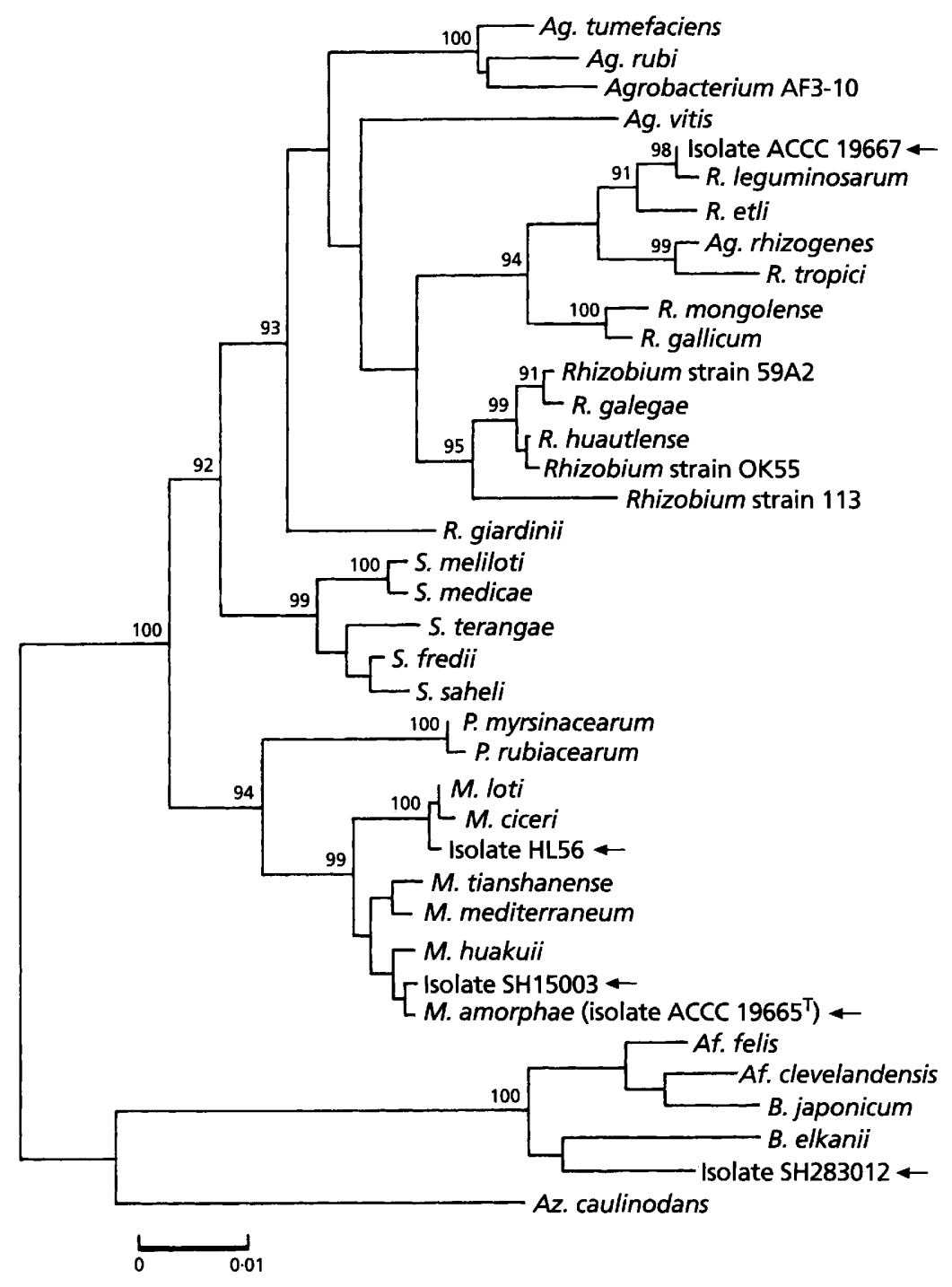

Fig. 3. Phylogenetic relationships of Mesorhizobium amorphae and several other isolates originating from Amorpha fruticosa within the $\alpha$-Proteobacteria based upon aligned sequences of the 165 rRNA genes. Jukes-Cantor distances and the neighbourjoining method were used to construct an optimal unrooted tree. Five hundred trees were generated in a bootstrap analysis to derive a majority rule consensus tree. The levels of support for the presence of nodes above a value of $90 \%$ are indicated in the tree. Representative sequences in the tree which were obtained from GenBank and used in the phylogenetic analysis were: Agrobacterium rubi (D14503), Agrobacterium vitis (D14502), Agrobacterium rhizogenes NCPPB2991 (D14501), Agrobacterium tumefaciens NCPPB2437 (D14500), Agrobacterium sp. strain AF3-10 (Z30542), Afipia clevelandensis (M69186), Afipia felis (M65248), Azorhizobium caulinodans (X94200), B. elkanii (U35000), B. japonicum (U69638), M. ciceri (U07934), M. huakuii (D13431), M. loti (X67229), M. mediterraneum (L38825), Phyllobacterium myrsinacearum (D12789), Phyllobacterium rubiacearum (D12790), $R$. etli (U28916), R. galegae (X67226), $R$. galegae strain 59A2 (AF025853), $R$. gallicum (U86343), R. giardinii (U86344), R. huautlense (AF025852), $R$. leguminosarum bv. viciae (U29386), $R$. mongolense (U89817), $R$. tropici (U89832), Rhizobium sp. strain OK 55 (D14510), Rhizobium sp. strain 113 (D14512), $S$. fredii (X67231), Sinorhizobium medicae (L39882), S. meliloti (X67222), S. saheli (X68390) and $S$. terangae (X68387). The sequences were aligned using the PILEUP program in the Wisconsin package of the Genetics Computer Group (Madison, WI, USA) and the aligned sequences were analysed using the Molecular Evolutionary Genetics Analysis (MEGA) package version 1.01 (Kumar et al., 1993). The scale bar shows $1 \%$ nucleotide substitutions.
From the 16S rRNA gene sequence data we concluded that the isolate ACCC 19667 was a member of the genus Rhizobium. Its 16S rRNA nucleotide sequence and that of the type strain for $R$. leguminosarum were $99.8 \%$ similar. In our current reconstruction $R$. galegae and Rhizobium huautlense had common ancestry with $R$. leguminosarum as we previously reported (Wang et al., 1998). The fifth isolate (SH283012) and the type strain for $B$. elkanii were distantly related since their 16S rRNA gene nucleotide sequences were only $97 \cdot 3 \%$ similar.

\section{Plasmid contents and symbiotic plasmid identification}

Five different plasmid profiles were observed among the isolates from Amorpha fruticosa. The number of plasmids observed ranged from none in the case of isolates SH28301 and SH283012 to four in the case of ACCC 19667 and ACCC 19677 (Table 1, Fig. 4). The majority of the isolates haboured one or two plasmids. With the exception of isolates SH28301 and SH283012, each of the isolates harboured a $930 \mathrm{~kb}$ plasmid. In isolates ACCC $19665^{\mathrm{T}}$, B104, SH190012, ACCC 19660, ACCC 19666, HL56, B276, SH15003 and N206, which represented groups within Mesorhizobium, the $930 \mathrm{~kb}$ plasmid appeared to be the symbiotic plasmid (pSym) since it hybridized with the cloned nodDAB genes of $R$. tropici CFN 299 and the cloned nifDHK genes of $R$. etli CFN $42^{\mathrm{T}}$. None of the plasmids of isolate ACCC 19667 hybridized with these two clones.

Because we observed a pSym in isolates from Amorpha fruticosa which were species within Mesorhizobium, we also examined reference strains within this genus for the presence of plasmid-borne symbiotic genes. Although we observed from one to three plasmids in NZP $2213^{\mathrm{T}}$ (M. loti), CCBAU $2609^{\mathrm{T}}(M$. huakuii),

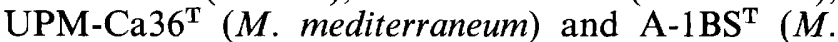
tianshanense), none hybridized with the nod and nif 


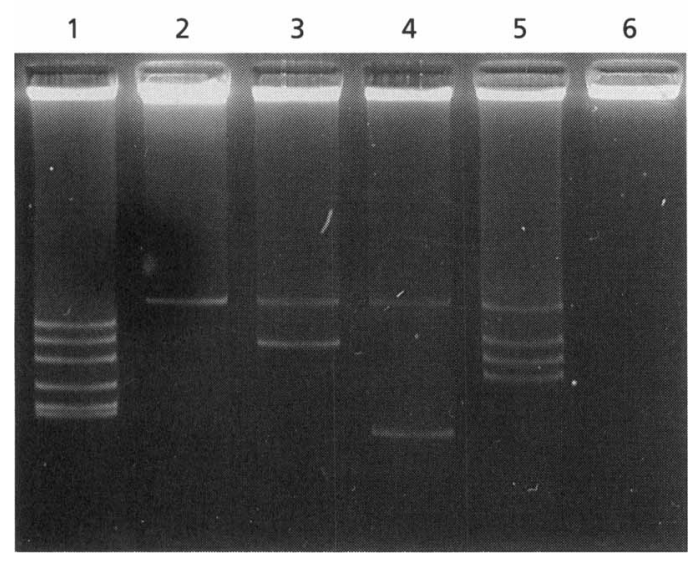

Fig. 4. Plasmid electrophoretic patterns obtained with $R$. et/i CFN $42^{\top}$ and isolates from Amorpha fruticosa. Lanes: 1, CFN $42^{\top}$ $(630,510,390,270,170$ and $150 \mathrm{~kb}) ; 2, \operatorname{ACCC} 19665^{\top}(930 \mathrm{~kb})$; 3, ACCC 19663 (930 and $550 \mathrm{~kb}$ ); 4, ACCC 19660 (930 and $150 \mathrm{~kb}) ; 5$, ACCC 19667 (930, 610, 490 and $440 \mathrm{~kb}) ; 6$, SH283012 (no plasmids). The plasmids were visualized by using a modified Eckhardt procedure (Hynes \& McGregor, 1990) and their mobilities were determined in $0.7 \%$ agarose gels. The approximate molecular sizes were estimated by using plasmids of CFN $42^{\top}$ as molecular size references.

genes tested. In the case of UPM-Ca $7^{\mathrm{T}}(M$. ciceri) and ORS 1037 (M. plurifarium) no plasmids were observed.

\section{Hybridization of nifH gene loci}

Only one nifH hybridization band was observed in both the EcoRI and BamHI digests of the DNAs of the isolates ACCC 19665 ${ }^{\mathrm{T}}$, HL56 and SH15003 (Fig. 5).
The molecular sizes of the EcoRI or BamHI restriction fragments hybridizing with nifH were the same across these three isolates. Weak to no hybridization signals were obtained with the nifH probe in analyses with the DNAs of isolates ACCC 19667 and SH283012 (Fig. 5).

\section{Phenotypic characterization}

The phenotypic characters of all the 55 isolates from Amorpha fruticosa are summarized in Table 4. Based upon phenotype, it was difficult to distinguish between group 1, represented by isolate ACCC $19665^{\mathrm{T}}$, and group 2, represented by HL56. Besides the presence of a pSym, the isolates within the three Mesorhizobium groups were distinguishable from the type strains for the species within Mesorhizobium by a combination of several phenotypic characters. These distinctive features are shown for the main group (group 1) of isolates from Amorpha fruticosa in Table 5.

\section{DISCUSSION}

Although Amorpha fruticosa was introduced into China approximately 50 years ago and was not inoculated, we observed that this legume host growing in Chinese soils was nodulated. The rhizobia which nodulated Amorpha fruticosa growing in Chinese soils were usually effective for nitrogen fixation since we isolated only 2 out of a total of 55 which were ineffective. Since Amorpha fruticosa is not native to China we are uncertain about the origin of the rhizobia which we isolated. It is possible that initially the rhizobia were seed-borne and were transmitted to China when the host was introduced, as has been suggested for the transmission of $R$. etli on seeds of (a)

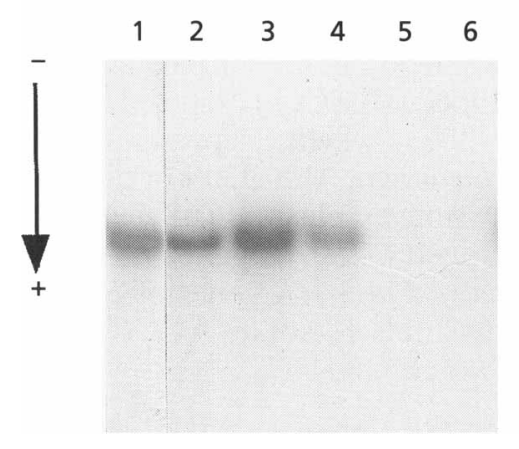

(b)

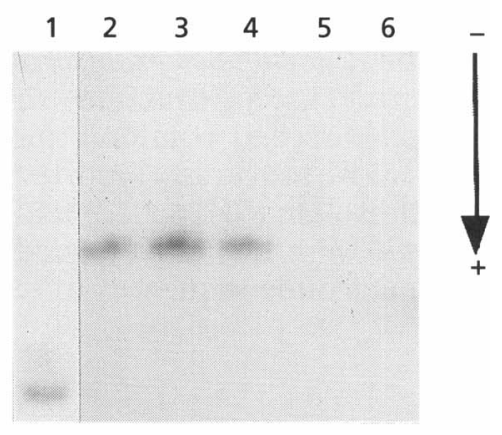

Fig. 5. Autoradiograms of Southern blots of total digested DNAs from $R$. etli CFN 299 and isolates from Amorpha fruticosa hybridized to a $600 \mathrm{bp}$ nifH fragment from $R$. et/i CFN $42^{\top}$ (Morett et al., 1988). (a) DNAs digested with EcoRI. Lanes: 1, CFN $299(8.1 \mathrm{~kb})$; 2, ACCC $19665^{\top}(7.8 \mathrm{~kb}) ; 3$, HL56 (7.8 kb); 4, SH15003 (7.8 kb); 5, ACCC 19667 (no band); 6 : SH283012 (no band). (b) DNAs digested with BamHI. Lanes: 1, CFN 299 (4.8 kb); 2, ACCC $19665^{\top}$ (8.3 kb); 3, HL56 (8.3 kb); 4, SH15003 (8.3 kb); 5, ACCC 19667 (no band); 6, SH283012 (no band). The molecular sizes of the fragments were estimated from their migration in $0.7 \%$ agarose gel and $\lambda$ DNA digested with BstEll was used as molecular size markers. Arrows show the electrophoretic direction. 
Table 4. Phenotypic characters and DNA G $+C$ content $\left(T_{m}\right)$ of isolates from Amorpha fruticosa

All the 55 isolates used L-arabinose, fumarate, rhamnose and L-xylose as sole carbon source. All grew at pH 5.0 and produced alkali in litmus milk. None grew with malonate, sorbose or lysine as sole carbon source. None grew at $\mathrm{pH} 9.0$ or at $37^{\circ} \mathrm{C}$ on YMA (Vincent, 1970). Values are the number of strains which showed growth, resistance or positive reactions.

\begin{tabular}{|c|c|c|c|c|c|}
\hline \multirow[t]{2}{*}{ Character } & \multicolumn{5}{|c|}{ Group* } \\
\hline & $1(n=43)$ & $2(n=6)$ & $3(n=2)$ & $4(n=2)$ & $5(n=2)$ \\
\hline \multicolumn{6}{|c|}{ Utilization as sole carbon source: } \\
\hline Acetate & 9 & 5 & 2 & 2 & 0 \\
\hline Citrate & 0 & 0 & 2 & 0 & 2 \\
\hline $\begin{array}{l}\text { D-Fructose, D-glucose, } \\
\text { meso-inositol, sucrose, } \\
\text { L-ornithine }\end{array}$ & 43 & 6 & 2 & 2 & 0 \\
\hline Malate & 43 & 5 & 2 & 0 & 2 \\
\hline Maltose & 42 & 6 & 2 & 2 & 1 \\
\hline D-Raffinose & 43 & 5 & 1 & 2 & 0 \\
\hline Saccharic acid & 1 & 0 & 0 & 1 & 1 \\
\hline$\beta$-Alanine & 43 & 6 & 2 & 0 & 0 \\
\hline \multicolumn{6}{|c|}{ Utilization as sole nitrogen source: } \\
\hline Arginine & 1 & 0 & 0 & 1 & 1 \\
\hline Glycine & 0 & 0 & 0 & 0 & 1 \\
\hline Lysine & 15 & 2 & 1 & 2 & 1 \\
\hline Methionine & 0 & 1 & 1 & 2 & 0 \\
\hline Phenylalanine & 4 & 6 & 2 & 2 & 1 \\
\hline Threonine & 29 & 6 & 1 & 2 & 0 \\
\hline Tryptophan & 15 & 4 & 2 & 0 & 2 \\
\hline Tyrosine & 43 & 6 & 2 & 2 & 0 \\
\hline \multicolumn{6}{|l|}{ Resistance to antimicrobials: } \\
\hline $\operatorname{Bacitracin}(10 \mathrm{U})$ & 3 & 0 & 1 & 0 & 0 \\
\hline Cefoperazone $(75 \mu \mathrm{g})$ & 43 & 6 & 2 & 2 & 0 \\
\hline Cefuroxime $(30 \mu \mathrm{g})$ & 41 & 6 & 0 & 2 & 0 \\
\hline Novobiocin $(30 \mu \mathrm{g})$ & 35 & 2 & 2 & 1 & 0 \\
\hline Polymyxin B (100 U) & 8 & 4 & 0 & 1 & 0 \\
\hline Ampicillin $(10 \mu \mathrm{g})$ & 41 & 6 & 1 & 2 & 0 \\
\hline Ciprofloxacin $(5 \mu \mathrm{g})$ & 25 & 6 & 2 & 2 & 0 \\
\hline Penicillin G (10 U) & 31 & 6 & 0 & 0 & 0 \\
\hline Streptomycin $(10 \mu \mathrm{g})$ & 30 & 1 & 1 & 0 & 0 \\
\hline Tetracycline $(30 \mu \mathrm{g})$ & 42 & 6 & 2 & 2 & 0 \\
\hline \multicolumn{6}{|l|}{ Others: } \\
\hline $\begin{array}{l}\text { Tolerance to } 1 \%(\mathrm{w} / \mathrm{v}) \\
\mathrm{NaCl}\end{array}$ & 13 & 1 & 1 & 0 & 1 \\
\hline $\begin{array}{l}\text { Tolerance to } 1.5 \%(\mathrm{w} / \mathrm{v}) \\
\mathrm{NaCl}\end{array}$ & 0 & 0 & 0 & 0 & 1 \\
\hline Growth in LB medium & 0 & 1 & 1 & 0 & 0 \\
\hline $\begin{array}{l}\text { Production of acid on } \\
\text { YMA }\end{array}$ & 43 & 6 & 2 & 2 & 0 \\
\hline $\begin{array}{l}\text { Production of alkali on } \\
\text { YMA }\end{array}$ & 0 & 0 & 0 & 0 & 2 \\
\hline Generation time (h) & $6-13$ & $9-12$ & $4-5$ & 4 & $14-15$ \\
\hline $\begin{array}{l}\text { DNA G }+\mathrm{C} \text { content } \\
(\mathrm{mol} \%)\left(T_{\mathrm{m}}\right)\end{array}$ & 64 & 64 & $61-63$ & 63 & 64 \\
\hline
\end{tabular}

${ }^{*}$ Groups defined on the basis of PCR-RFLP analysis of 16S rRNA genes (see Table 1). $n$ is the number of strains in the group. 
Table 5. Characters distinguishing $M$. amorphae from other Mesorhizobium species

The distinguishing features were chosen according to Jarvis et al. (1997). Species: 1, M. amorphae; 2, M. ciceri; 3, M. huakuii; 4, $M$. loti $; 5, M$. mediterraneum; $6, M$. tianshanense.,$+>95$ strains showed positive reaction (growth);,$->95 \%$ strains showed negative reaction (no growth); d, more than $5 \%$ but less than $95 \%$ strains showed positive reaction. ND, Not done; NO, not observed.

\begin{tabular}{|c|c|c|c|c|c|c|}
\hline Character & 1 & 2 & 3 & 4 & 5 & 6 \\
\hline $\begin{array}{l}\text { Maximum temperature for } \\
\text { growth }\left({ }^{\circ} \mathrm{C}\right)\end{array}$ & $<37$ & 40 & $37-39$ & 39 & 40 & ND \\
\hline $\begin{array}{l}\text { Maximum } \mathrm{NaCl} \text { conen for } \\
\text { growth }(\%, w / v)\end{array}$ & $\leqslant 1 \cdot 0$ & $2 \cdot 0$ & ND & $2 \cdot 0$ & $2 \cdot 0$ & $1 \cdot 0$ \\
\hline $\mathrm{pH}$ growth range & $5 \cdot 0,<9 \cdot 0$ & $5 \cdot 0-10 \cdot 0$ & $5 \cdot 0-9 \cdot 5$ & $4 \cdot 0,<10 \cdot 0$ & $5 \cdot 0,<10 \cdot 0$ & ND \\
\hline $\begin{array}{l}\text { DNA G }+C \text { content } \\
(\mathrm{mol} \%)\end{array}$ & 64 & $63-64$ & $59-64$ & $59-64$ & $63-64$ & $59-63$ \\
\hline \multicolumn{7}{|l|}{ Diameter of colonies: } \\
\hline Incubation (d) & 7 & $3-5$ & $5-6$ & 7 & $4-5$ & $5-7$ \\
\hline Size $(\mathrm{mm})$ & $\leqslant 1 \cdot 0$ & $2 \cdot 0-4 \cdot 0$ & $2 \cdot 0-4 \cdot 0$ & $1 \cdot 0$ & $>2 \cdot 0$ & $1 \cdot 0-2 \cdot 0$ \\
\hline Symbiotic plasmid size $(\mathrm{kb})$ & 930 & No & NO & No & No & No \\
\hline \multicolumn{7}{|c|}{ Substrates used as sole carbon sources: } \\
\hline Fumarate, D/L-malonate & + & + & + & + & + & - \\
\hline meso-Inositol & + & + & - & + & + & - \\
\hline D-Raffinose & + & - & + & $\mathrm{d}$ & - & d \\
\hline L-Lysine & - & - & + & + & $\mathrm{d}$ & d \\
\hline L-Ornithine & $\mathrm{d}$ & + & + & - & - & $\mathrm{d}$ \\
\hline$\beta$-Alanine & + & + & $\mathrm{d}$ & - & - & + \\
\hline L-Xylose & + & + & + & - & - & + \\
\hline
\end{tabular}

Phaseolus vulgaris (Pérez-Ramirez et al., 1998). Alternatively, Chinese soils may harbour rhizobia which are able to nodulate Amorpha fruticosa, but which more usually form symbioses with native legumes. There is some precedence for the opportunistic nodulation of introduced legume species by indigenous rhizobia (Martínez-Romero \& Caballero-Mellado, 1996). A comparative analysis of our Chinese isolates and those from the Americas may provide more insight into their origin.

The isolates from Amorpha fruticosa were examined using a polyphasic approach, which revealed genetic, phylogenetic and phenotypic characters of bacterial diversity. Generally, the results from each of the different approaches we used agreed. The 55 isolates were divided into five groups or genomic species, which were associated with three genera. The isolates were variable in their symbiotic effectiveness even if they belonged to the same genus. Phenotypes of growth rate and acid or alkali production on YMA distinguished isolates within the different genera. Variation among isolates within the genus level was demonstrated with results of MLEE, growth in the presence of $1.5 \% \mathrm{NaCl}$ and differences in utilization of carbon and nitrogen sources.

We concluded from our investigation that the majority of the rhizobia originating from nodules of Amorpha fruticosa growing in Chinese soils are species within the genus Mesorhizobium. The 16S rRNA genes of the isolates in groups 1-3 were most similar to those of the type strains for the species within Mesorhizobium (Jarvis et al., 1997). Phenotypically, these isolates also had the characteristics of Mesorhizobium since they had moderate to slow growth rates and produced acid on YMA (Jarvis et al., 1997). Also, we established that the fast-growing, acid-producing, ineffective isolates were species of Rhizobium, and were most probably $R$. leguminosarum on the basis of the relatively high DNA homology $(70 \%$, Table 3) between isolate ACCC 19667 and the type strain of the species, USDA 2370. Even though this isolate was identified as $R$. leguminosarum, it does not possess the symbiotic determinants to nodulate Pisium sativum and Phaseolus vulgaris, hosts more commonly associated with this rhizobial species. The ineffective response on Amorpha fruticosa may not necessarily be because of their genus affiliation since $R$. tropici CFN 299 was effective with this host. Finally, we concluded that the remaining two isolates (group 5) were species of Bradyrhizobium based upon results from the $16 \mathrm{~S}$ rRNA analysis and growth rate experiments. However, these isolates were distinct from $B$. japonicum and B. elkanii because of low DNA homology (Table 3).

Sequences of the 16S rRNA genes are most commonly used in the reconstruction of bacterial phylogenies (Maidak et al., 1994). In our current reconstruction of the phylogeny of the isolates from Amorpha fruticosa, the position of $R$. galegae would indicate common ancestry with $R$. leguminosarum rather than with 
Agrobacterium vitis. We first reported this new relationship between $R$. galegae, $R$. leguminosarum and Agrobacterium vitis when we proposed $R$. huautlense as a new species (Wang et al., 1998). Most previously published phylogenies have indicated a commmon ancestry between $R$. galegae and Agrobacterium vitis (Amarger et al., 1997; de Lajudie et al., 1994; Tan et al., 1997; van Berkum et al., 1998a; Willems \& Collins, 1993; Yanagi \& Yamasato, 1993; Young \& Haukka, 1996), which has resulted in a debate regarding whether to change the genus affiliation of $R$. galegae from Rhizobium to Agrobacterium (de Lajudie et al., 1994; Young \& Haukka, 1996). The difference in the phylogenetic relationships in our reconstruction probably result from the addition of sequences similar to that of R. galegae (Wang et al., 1998) or perhaps from the different algorithms used to reconstruct phylogenetic trees. However, low bootstrap confidence values at the nodes separating $R$. galegae and other species of Rhizobium and Agrobacterium (Wang et al., 1998) indicate that further changes may occur when additional related sequences are added. Therefore, we suggest the more cautious approach of retaining $R$. galegae within the genus Rhizobium and waiting for more evidence before reassignment of its genus affiliation.

The species within the genera Rhizobium and Sinorhizobium carry their determinants for symbiosis on plasmids (Martínez-Romero et al., 1990). Species within the genera Bradyrhizobium and Mesorhizobium have been reported to carry their genes for symbiosis on the chromosome and a pSym is absent (Jarvis et al., 1997; Martínez-Romero et al., 1990). Here, we describe a common symbiotic plasmid $(930 \mathrm{~kb})$ as well as some intrinsic plasmids (150 or $550 \mathrm{~kb})$ among the isolates within the genus Mesorhizobium. The presence of a pSym within Mesorhizobium is an unusual characteristic. However, there may be a precedence for the existence of a pSym in some species of the genus because Xu \& Murooka (1995) indicated that the genes required for symbiosis in some $M$. huakuii strains were located on a large plasmid. However, we were unable to confirm this for the type strain of this species in our analysis.

All the isolates within Mesorhizobium had symbiotic plasmids of similar molecular size and had similar nifH gene hybridization patterns. From this evidence we concluded that these isolates shared the same pSym, indicating that the symbiotic genes may have been inherited through genetic exchange. However, the symbiotic genes of the isolates belonging to the other two genera were probably different since there were low or no hybridization signals with both the $\operatorname{nod} D A B$ and $n i f H$ probes we used.

None of the 16S rRNA gene sequences of the isolates within Mesorhizobium and those of the reference strains for species within Mesorhizobium were identical. However, this difference alone is insufficient evidence for their separate speciation (Stackebrandt \&
Goebel, 1994). Therefore, we used several additional approaches to determine whether our isolates belonged to any of the recognized species within the genus Mesorhizobium. Based upon the polyphasic approach of our investigation we conclude that the three groups represented by isolates ACCC $19665^{\mathrm{T}}$, HL56 and SH15003 are different from the described species of this genus. However, differences among the three groups were less distinct and, therefore, we hesitate to separate them into three different species. A possibility would be to classify them as different types within a single species, as for $R$. tropici (Martínez-Romero et al., 1991) and M. plurifarium (de Lajudie et al., 1998). However, for the moment, we prefer to propose only the most distinct group (group 1) as a new species within the genus Mesorhizobium, Mesorhizobium amorphae.

\section{Description of Mesorhizobium amorphae sp. nov.}

Mesorhizobium amorphae (a.mor'phae. N.L. n. Amorpha a systematic genus name of legume plants; N.L. gen. n. amorphae of Amorpha, the legume genus with which the species forms nitrogen-fixing symbioses).

Gram-negative, aerobic, non-spore-forming rods with cell size of $0.47-1.68 \times 0.41-0.65 \mu \mathrm{m}$, which produce acid on YMA and alkali in litmus milk. Colonies on solid media are circular, translucent and with a diameter of $1 \mathrm{~mm}$ after $7 \mathrm{~d}$ growth at $28^{\circ} \mathrm{C}$. The generation times are from 6 to $13 \mathrm{~h}$ in YM broth. The maximum temperature for growth is below $37^{\circ} \mathrm{C}$. Growth on YMA is inhibited by $1.5 \%(\mathrm{w} / \mathrm{v}) \mathrm{NaCl}$ and by a $\mathrm{pH}$ higher than $9 \cdot 0$. The species is resistant to cefoperazone $(75 \mu \mathrm{g})$ and tetracycline $(30 \mu \mathrm{g})$, uses Larabinose, D-fructose, fumarate, D-glucose, meso-inositol, rhamnose, sucrose, L-xylose, $\beta$-alanine and ornithine as sole carbon sources, and tyrosine, $\mathrm{NH}_{4} \mathrm{Cl}$ and $\mathrm{NH}_{4} \mathrm{SO}_{4}$ as sole nitrogen sources. The genes for symbiosis reside on a $930 \mathrm{~kb}$ plasmid. There is only one nifH gene copy. No evidence was obtained that the reference isolate, ACCC $19665^{\mathrm{T}}$, formed symbioses with any other host plant except for Amorpha fruticosa. The type strain is ACCC $19665^{\mathrm{T}}$ and it has the characteristics described for the species.

\section{ACKNOWLEDGEMENTS}

This work was partly supported by the Natural Science Foundation of China, by USDA-FAS-OICD-RSED, USA, and by DGAPA IN202097 from UNAM, Mexico. We thank Dr D. Romero, Dr J. Caballero-Mellado and M. A. RogelHernández for help and K. Lee Nash for technical support.

\section{REFERENCES}

Allen, O. N. \& Allen, E. K. (1981). The Leguminosae: a Source Book of Characteristics, Uses, and Nodulation. Madison, WI: University of Wisconsin Press.

Amarger, N., Marcheret, V. \& Laguerre, G. (1997). Rhizobium 
gallicum sp. nov. and Rhizobium giardinii sp. nov. from Phaseolus vulgaris nodules. Int J Syst Bacteriol 47, 996-1006.

van Berkum, P. (1990). Evidence for a third uptake hydrogenase phenotype among the soybean bradyrhizobia. Appl Environ Microbiol 56, 3835-3841.

van Berkum, P., Beyene, D. \& Eardly, B. D. (1996). Phylogenetic relationships among Rhizobium species nodulating the common bean (Phaseolus vulgaris L.). Int J Syst Bacteriol 46, $240-244$.

van Berkum, P., Beyene, D., Bao, G., Campbell, T. A. \& Eardly, B. D. (1998a). Rhizobium mongolense sp. nov., is one of three rhizobial genotypes identified which nodulate and form nitrogen-fixing symbioses with Medicago ruthenica [(L.) Ledebour]. Int J Syst Bacteriol 48, 13-22.

van Berkum, P., Ruihua, F., Campbell, T. A. \& Eardly, B. D. (1998b). Some issues of relevance in the taxonomy of rhizobia. In Highlights on Nitrogen Fixation Research. Edited by $\mathrm{E}$. Martínez \& G. Hernández. New York: Plenum (in press).

Brown, A. H. D., Feldman, M. W. \& Nevo, E. (1980). Multilocus structure of natural populations of Hordeum spontaneum. Genetics 96, 523-536.

Caballero-Mellado, J. \& Martínez-Romero, E. (1994). Limited genetic diversity in the endophytic sugarcane bacterium Acetobacter diazotrophicus. Appl Environ Microbiol 60, 1532-1537.

Chen, W. X., Wang, E. T, Wang, S. Y., Li, Y. B., Chen, X. Q. \& Li, Y. (1995). Characterization of Rhizobium tianshanense sp. nov., a moderately and slowly growing root nodule bacterium isolated from an arid saline environment in Xinjiang, People's Republic of China. Int J Syst Bacteriol 45, 153-159.

Chen, W. X., Yan, G. H. \& Li, J. L. (1988). Numerical taxonomic study of fast-growing soybean rhizobia and a proposal that Rhizobium fredii be assigned to Sinorhizobium gen. nov. Int $J$ Syst Bacteriol 38, 392-398.

Chirgwin, J. M., Przybyla, A. E., MacDonald, R. J. \& Rutter, W. J. (1979). Isolation of biologically active ribonucleic acid from sources enriched in ribonuclease. Biochemistry 18, 5294-5299.

Cilia, V., Lafay, B. \& Christen, R. (1996). Sequence heterogeneities among $16 \mathrm{~S}$ ribosomal RNA sequences and their effect on phylogenetic analyses at the species level. Mol Biol Evol 13, 451-461.

De Ley, J. (1970). Re-examination of the association between melting point, buoyant density, and chemical base composition of DNA. J Bacteriol 101, 738-754.

Dreyfus, B., Garcia, J. L. \& Gillis, M. (1988). Characterization of Azorhizobium caulinodans gen. nov., sp. nov., a stem-nodulating nitrogen-fixing bacterium isolated from Sesbania rostrata. Int $J$ Syst Bacteriol 38, 89-98.

Eardly, B. D., Wang, F. S., Whittam, T. S. \& Selander, R. K. (1995). Species limits in Rhizobium populations that nodulate the common bean (Phaseolus vulgaris). Appl Environ Microbiol 58, 1809-1815.

Eckhardt, T. (1978). A rapid method for the identification of plasmid deoxyribonucleic acid in bacteria. Plasmid 1, 584-588.

Geniaux, E., Flores, M., Palacios, R. \& Martínez, E. (1995). Presence of megaplasmids in Rhizobium tropici and further evidence of differences between the two $R$. tropici subtypes. Int $J$ Syst Bacteriol 45, 392-394.

Graham, P. H., Sadowsky, M. J., Keyser, H. H. \& 8 other authors (1991). Proposed minimal standards for the description of new genera and species of root- and stem-nodulating bacteria. Int $J$ Syst Bacteriol 41, 582-587.
Hynes, M. F. \& McGregor, N. F. (1990). Two plasmids other than the nodulation plasmid are necessary for formation of nitrogenfixing nodules by Rhizobium leguminosarum. Mol Microbiol 4, 567-574.

Jarvis, B. D. W., van Berkum, P., Chen, W. X., Nour, S. M., Fernandes, M. P., Cleyet-Marel, J. C. \& Gillis, M. (1997). Transfer of Rhizobium loti, Rhizobium huakuii, Rhizobium ciceri, Rhizobium mediterraneum, and Rhizobium tianshanense to a new genus: Mesorhizobium. Int J Syst Bacteriol 47, 895-898.

Jordan, D. C. (1984). Family III. Rhizobiaceae. In Bergey's Manual of Systematic Bacteriology, vol. 1, pp. 234-242. Edited by N. R. Krieg \& J. G. Holt. Baltimore: Williams \& Wilkins.

Jukes, T. H. \& Cantor, C. R. (1969). Evolution of protein molecules. In Mammalian Protein Metabolism, pp. 21-132. Edited by H. N. Munro. New York: Academic Press.

Konoshima, T., Terada, H., Kokumai, M., Kozuka, M., Tokuda, H., Estes, J. R., Li, L., Wang, H. K. \& Lee, K. H. (1993). Studies on inhibitors of skin tumour promotion. XII. Rotenoids from Amorpha fruticosa. J Nat Prod (Lloydia) 56, 843-848.

Kumar, S., Tamura, K. \& Nei, M. (1993). MEGA: Molecular Evolutionary Genetics Analysis, version 1.01. The Pennsylvania State University, University Park, PA 16802, USA.

Ladha, J. K. \& So, R. B. (1994). Numerical taxonomy of photosynthetic rhizobia nodulating Aeschynomene species. Int J Syst Bacteriol 44, 62-73.

Laguerre, G., Allard, M., Revoy, F. \& Amarger, N. (1994). Rapid identification of rhizobia by restriction fragment length polymorphism analysis of PCR-amplified 16S rRNA genes. Appl Environ Microbiol 61, 56-63.

de Lajudie, P., Willems, A., Pot, B. \& 7 other authors (1994). Polyphasic taxonomy of rhizobia: emendation of the genus Sinorhizobium and description of Sinorhizobium meliloti comb. nov., Sinorhizobium saheli sp. nov., and Sinorhizobium teranga sp. nov. Int $J$ Syst Bacteriol 44, 715-733.

de Lajudie, P., Willems, A., Nick, G. \& 9 other authors (1998). Characterization of tropical tree rhizobia and description of Mesorhizobium plurifarium sp. nov. Int $J$ Syst Bacteriol 48, 369-382.

Leonard, L. T. (1943). A simple assembly for use in the testing for cultures of rhizobia. J Bacteriol 45, 523-527.

Maidak, B. L., Larsen, N., McCaughey, M. J., Overbeek, R., Olsen, G. J., Fogel, K., Blandy, J. \& Woese, C. R. (1994). The ribosomal database project. Nucleic Acids Res 22, 3485-3487.

Martínez, E., Palacios, R. \& Sánchez, F. (1987). Nitrogen-fixing nodules induced by Agrobacterium tumefaciens harboring Rhizobium phaseoli plasmids. J Bacteriol 169, 2828-2834.

Martínez, E., Romero, D. \& Palacios, R. (1990). The Rhizobium genome. Crit Rev Plant Sci 9, 59-93.

Martínez-Romero, E. \& Caballero-Mellado, J. (1996). Rhizobium phylogenies and bacterial genetic diversity. Crit Rev Plant Sci 15, 113-140.

Martínez-Romero, E., Segovia, L., Mercante, F. M., Franco, A. A., Graham, P. \& Pardo, M. A. (1991). Rhizobium tropici, a novel species nodulating Phaseolus vulgaris L. beans and Leucaena $\mathrm{sp.}$ trees. Int J Syst Bacteriol 41, 417-426.

Maynard Smith, J., Smith, N. H., O'Rourke, M. \& Spratt, B. G. (1993). How clonal are bacteria? Proc Natl Acad Sci USA 90, 43844388.

Mitscher, L. A., Park, Y. H., Al-Shamma, A., Hudson, P. B. \& Haas, T. (1981). Amorfrutin A and B, bibenzyl antimicrobial agents from Amorpha fruticosa. Phytochemistry 20, 781-785. 
Morett, E., Moreno, S. \& Espin, G. (1988). Transcription analysis of the three nifH genes of Rhizobium phaseoli with gene fusion. Mol Gen Genet 213, 499-504.

Navarro, R. B., Vargas, A. A. T., Schroder, E. C. \& van Berkum, P. (1993). Uptake hydrogenase (Hup) in common bean (Phaseolus vulgaris) symbioses. Appl Environ Microbiol 60, 4162-4165.

Nei, M. \& Li, W. H. (1979). Mathematical model for studying genetic variation in terms of restriction endonucleases. Proc Natl Acad Sci USA 76, 5269-5273.

Noel, K. D., Sánchez, F., Fernandez, F., Leemans, J. \& Cevallos, A. (1984). Rhizobium phaseoli symbiotic mutants with transposon Tn5 insertions. J Bacteriol 158, 148-155.

Oyaizu, H., Matsumoto, S., Minamisawa, K. \& Gamou, T. (1993). Distribution of rhizobia in leguminous plants surveyed by phylogenetic identification. J Gen Appl Microbiol 39, 339-354.

Pérez-Ramirez, N. O., Rogel-Hernández, M. A., Wang, E. T. \& Martínez-Romero, E. (1998). Seeds of Phaseolus vulgaris bean carry Rhizobium etli. FEMS Microbiol Ecol 26, 289-296.

Piñero, D., Martínez, E. \& Selander, R. K. (1988). Genetic diversity and relationships among isolates from Rhizobium leguminosarum biovar phaseoli. Appl Environ Microbiol 54, 2825-2832.

Rhoads, D. D. \& Roufa, D. J. (1989). Seqaid II (tm) version 3.5. Molecular Genetics Laboratory, Kansas State University, KS, USA.

Romero, D., Brom, S., Martínez-Salazar, J., de Lourdes Girard, M., Palacios, R. \& Davila, G. (1991). Amplification and deletion of a nod-nif region in the symbiotic plasmid of Rhizobium phaseoli. $J$ Bacteriol 173, 2435-2441.

Saitou, N. \& Nei, M. (1987). The neighbor-joining method: a new method for reconstructing phylogenetic trees. Mol Biol Evol 4, $406-425$

Segovia, L., Young, J. P. W. \& Martínez-Romero, E. (1993). Reclassification of American Rhizobium leguminosarum biovar phaseoli type I strains as Rhizobium etli sp. nov. Int J Syst Bacteriol 43, 374-377.

Selander, R. K., Caugant, D. A., Ochman, H., Musser, J. M., Gilmour, M. N. \& Whittam, T. S. (1986). Methods of multilocus enzyme electrophoresis for bacterial population genetics and systematics. Appl Environ Microbiol 51, 873-884.

Sneath, P. H. A. \& Sokal, R. R. (1973). Numerical Taxonomy. San Francisco: Freeman

Souza, V., Nguyen, T. T., Hudson, R. R., Piñero, D. \& Lenski, R. E. (1992). Hierarchical analysis of linkage disequilibrium in Rhizobium populations: evidence for sex? Proc Natl Acad Sci USA 89, 8389-8393.

Stackebrandt, E. \& Goebel, B. M. (1994). Taxonomic note: a place for DNA-DNA reassociation and 16S rRNA sequence analysis in the present species definition in bacteriology. Int $J$ Syst Bacteriol 44, 846-849.

Sullivan, J. T., Patrick, H. N., Lowther, W. L., Barry Scott, D. \& Ronson, C. W. (1995). Nodulating strains of Rhizobium loti arise through chromosomal symbiotic gene transfer in the environment. Proc Natl Acad Sci USA 92, 8985-8989.

Sullivan, J. T., Eardly, B. D., van Berkum, P. \& Ronson, C. W. (1996). Four unnamed species of nonsymbiotic rhizobia isolated from the rhizosphere of Lotus corniculatus. Appl Environ Microbiol 62, 2818-2825.

Tan, Z. Y., Xu, X. D., Wang, E. T., Gao, J. L., Martínez-Romero, E. \& Chen, W. X. (1997). Phylogenetic and genetic relationships of Mesorhizobium tianshanense and related rhizobia. Int $J$ Syst Bacteriol 47, 874-879.

Vincent, J. M. (1970). A Manual for the Practical Study of Rootnodule Bacteria. IBP handbook 15. Oxford: Blackwell Scientific Publications.

Wang, Y., Zhang, Z. \& Ramanan, N. (1997). The actinomycete Thermobispora bispora contains two distinct types of transcriptionally active $16 \mathrm{~S}$ rRNA genes. J Bacteriol 179, 3270-3276.

Wang, E. T., van Berkum, P., Beyene, D., Sui, X. H., Dorado, O., Chen, W. X. \& Martínez-Romero, E. (1998). Rhizobium huautlense sp. nov., a symbiont of Sesbania herbacea that has a close phylogenetic relationship with Rhizobium galegae. Int J Syst Bacteriol 48, 687-699.

Weisburg, W. G., Barns, S. M., Pelletier, D. A. \& Lane, D. J. (1991). 16S ribosomal DNA amplification for phylogenetic study. $J$ Bacteriol 173, 697--703.

Willems, A. \& Collins, D. (1993). Phylogenetic analysis of rhizobia and agrobacteria based on $16 \mathrm{~S}$ rRNA gene sequence. Int $J$ Syst Bacteriol 43, 305-313.

Xu, Y. \& Murooka, Y. (1995). A large plasmid isolated from Rhizobium huakuii bv Renge that includes genes for both nodulation of Astragalus sinicus cv. Japan and nitrogenfixation. $J$ Ferment Bioeng 80, 276-279.

Yanagi, M. \& Yamasato, K. (1993). Phylogenetic analysis of the family Rhizobiaceae and related bacteria by sequencing of $16 \mathrm{~S}$ rRNA gene using PCR and DNA sequencer. FEMS Microbiol Lett 107, 115-120.

Yelton, M. M., Yang, S. S., Edie, S. A. \& Lim, S. T. (1983). Characterization of an effective salt-tolerant, fast-growing strain of Rhizobium japonicum. J Gen Microbiol 129, 1537-1547.

Young, J. P. W. (1985). Rhizobium population genetics: enzyme polymorphism in isolates from peas, clover, beans and lucerne grown in the same site. J Gen Microbiol 131, 2389-2408.

Young, J. P. W. \& Haukka, K. E. (1996). Diversity and phylogeney of rhizobia. New Phytol 133, 87-94. 